Marco A E Marcus MD, Frans L Bruyninckx MDt, Jan D Vertommen MD, PHDf, Patrick F Wouters MD, PHD†, Hugo Van Aken MD, FRCA, PHD

\section{Spinal somatosensory evoked potentials after epidural isoproterenol in awake sheep}

Purpose: The use of 10-15 $\mu \mathrm{g}$ epinephrine as an epidural test-dose is controversial. Isoproterenol would be a better alternative. However before $5 \mu \mathrm{g}$ isoproterenol can be incorporated in an epidural test-dose. neurotoxicological studies have to be performed. The present study was designed to assess

spinal somatosensory evoked potentials (spinal SSEP) before and after epidural isoproteronol.

Methods: Spinal SSEPs were recorded before, $30 \mathrm{~min}$ after, and $72 \mathrm{hr}$ after $50 \mu \mathrm{g}$ isoproterenol were given epidurally $\left(L_{3-4}\right)$ to six chronically instrumented awake sheep. The spinal SSEPs after epidural $\left(L_{3-4}\right)$ administration of $15 \mathrm{ml}$ lidocaine $2 \%$ were used to evaluate the model. The SSEPs were generated by transcutaneous stimulation of the sciatic nerve in the thigh. Spinal SSEPs were recorded directly from the spinal cord at vertebra $T_{12}$ using a monopolar epidural electrode referenced to a subcutaneous needle electrode in the adjacent paraspinal area.

Results: Thirty minutes and $72 \mathrm{hr}$ after epidural injection of $50 \mu \mathrm{g}$ isoproterenol the latency and the amplitude of the SSEP waves were similar to baseline values. After lidocaine, no SSEPs could be generated in three sheep while in three sheep the latency of wave $2(W 2$ ) was prolonged and the amplitude diminished.

Conclusion: Administration of epidural isoproterenol did not affect spinal SSEPS in this study indicating an absence of neurotoxic side effects.

Objectif : L'utilisation de 10-15 $\mu \mathrm{g}$ d'épinéphrine comme dose-test de l'anesthésie épidurale est contestée. Lisoprotérénol devrait être une meilleure solution de rechange. Cependant, avant d'incorporer $5 \mu \mathrm{g}$ d'isoprotérénol à une dose-test épidurale, il faut effectuer des études de neurotoxicité. L'étude actuelle visait à mesurer les potentiels évoqués somatosentoriels (SS) spinaux avant et après de l'isoprotérénol épidural.

Méthodes : Les SSEP spinaux ont été enregistrés avant, 30 min après et $72 \mathrm{~h}$ après l'administration épidurale de 50ug d'isoprotérénol $\left(\mathrm{L}_{3}-\mathrm{L}_{4}\right)$ à six préparations de moutons éveillés. Les SSEP spinaux enregistrés après l'administration de $15 \mathrm{ml}$ de lidocaine $2 \%$ ont servi à valider le modèle. Les SSEP ont été générés par stimulation transcutanée du nerf sciatique au niveau de la cuisse. Les SSEP spinaux ont été enregistrés directernent sur la moelie au niveau de $\mathrm{T}_{12}$ avec une électrode unipolaire ; l'électrode de référence était une aiguille sous-cutanée insérée dans la région paraspinale adjacente.

Résultats : Trente minutes et $72 \mathrm{~h}$ après l'injection épidurale de $50 \mu \mathrm{g} d$ ' isoprotérénol, la latence et l'amplitude des ondes SSEP étaient identiques aux valeurs initiales. Après la lidocaïne, les SSEP ne pouvaient être générés chez trois moutons alors que chez les trois autres, la latence de l'Onde 2 (W2) était prolongée et son amplitude diminuée.

Conclusion : Pendant cette étude, l'administration d'isoprotérénol épidural n'a pas affecté les SSEP spinaux, ce qui démontre l'absence d'effets neurotoxiques.

From the Klinik und Poliklinik für Anästhesiologie und operative intensivmedizin, Westfalischen-Wilhelms Universität, Münster, Germany, and the department of Physical Medicine and Rehabilitationt, and the department of Anesthesiology, University Hospitals, Katholieke Lniversiteit Leuven, Belgium.

The study was performed at the Center of Experimental Surgery and Anesthesiology, University Hospitals, Katholicke Uniwersiteit Leuven. Presented in part at the annual IARS meeting, March 1995, Honolulu, Hawaii.

Address correspondence to: Dr. Hugo Van Aken, Westfâlische Wilhelms Univ., Albert-Schweitzer-Strasse 33, D.48149 Münster,

Germany, tel. 49-251-837251, fax 49-251-88704

Accepted for Publication August 31, 1996. 
A DMINISTRATION of a test dose containing epinephrine is recommended for the detection of inadvertent intravascular placement or migration of an epidural catheter. However, previous studies have shown that injection of $15 \mu \mathrm{g}$ epinephrine $i v$ decreases uterine blood flow (UBF) by up to $60 \%$ for three minutes in pregnant ewes. ${ }^{1}$ Furthermore, an increase in heart rate is not always obvious in the parturient after injection of an epinephrine containing test dose. Also, there is a high incidence of false-positive ${ }^{2}$ and false-negative results $^{3}$ in mothers and baseline heart rates are highly variable. Although the chronotropic response in term pregnant women is reduced, Leighton et al stated that a test dose containing $5 \mu \mathrm{g}$ isoproterenol might be a safer and more effective alternative. ${ }^{3,4}$ However, before isoproterenol can be incorporated as an epidural test-dose neurotoxicological studies have to be performed.

Histopathological evaluation, spinal cord blood flow and somatosensory evoked potentials can be used to evaluate of the integrity of the spinal cord. The value of somatosensory evoked potentials to assess spinal cord dysfunction has been well documented. ${ }^{5-7}$

The present study was designed to assess the spinal somatosensory evoked potentials (spinal SSEP) before, $30 \mathrm{~min}$ after, and $72 \mathrm{hr}$. after $50 \mu \mathrm{g}$ isoproterenol were given epidurally to chronically instrumented awake sheep. The spinal SSEPs after lidocaine were used to evaluate the model.

\section{Methods}

After approval by the Committee on Animal Research, Katholieke Universiteit Leuven, six ewes were studied.

Under general anaesthesia, an epidural needle was placed between spinal processes $T_{11-12}$, using the loss of resistance technique, until it reached its desired position against the spinal dura. Then, a recording electrode was inserted through the lumen of the needle after which the needle was withdrawn. Similarly, an epidural catheter was inserted between lumbar processes $\mathrm{L}_{3-4}$. After recovery from anaesthesia, the animals were allowed to stabilize for $72 \mathrm{hr}$.

The animals were studied awake standing in a study cart. Spinal SSEPs were generated by transcutaneous electrical stimulation of the sciatic nerve at the posterior mid-thigh level. Stimulation was applied through a stimulating unit consisting of parallel, curved blunt metal rods mounted on perspex. Inter-electrode distance was $1.5 \mathrm{~cm}$ and the cathode was placed proximal to the anode. After the area was shaved this unit was pressed transcutaneously against the sciatic nerve and electric shock stimulation, square wave pulses of 0.1 msec duration and 100-200 $\mathrm{V}$ amplitude, was applied via a stimulus isolation unit at a frequency of $3-5 \mathrm{~Hz}$. These intensities usually evoke some contraction of local hind limb muscles, but did not appear to cause discomfort to the sheep. Stimulation voltage was constant throughout each experiment. Room temperature was kept high. Rectal temperature was recorded before and after each experiment and did not differ.

Spinal SSEPs were recorded directly from the spinal cord at vertebra $T_{12}$ using a monopolar epidural electrode referenced to a subcutaneous needle electrode in the adjacent para-spinal area. This recording electrode (Nicolet, ref. 019-405600) consists of a stainless steel tip ( $1 \mathrm{~mm}$ diameter, $5 \mathrm{~mm}$ length) mounted on a 120 $\mathrm{mm}$ flexible Teflon coated wire. A stainless steel ground plate electrode was taped to a shaved area of the upper thigh and conductive paste was used to ensure good contact. Signals were fed via a pre-amplifier to an amplifier with a signal averaging unit. A standard, commercially available, electromyography apparatus was used (Medelec MS 92, Vickers Medical, Old Woking, England). This device includes a stimulus generator, as well as units for amplifying, processing, displaying and printing of the recorded signals. The frequency band was $20 \mathrm{~Hz}$ to $2 \mathrm{kHz}$. When stable, reproducible waveforms were present, they were averaged.

Signals containing large amplitude interference were rejected. An artifact rejection facility is incorporated into the averager of the Medelec MS 92. When a signal overload of about 2.6 vertical divisions on the screen (in our work corresponding to $50 \mu \mathrm{V}$ ) is detected, this is identified as an artifact, and that section of the recording is rejected by the averager. There are several causes of overload e.g. electrical stimulus artifacts or by movement artifact. The SSEP waveforms were displayed on an oscilloscope where peak latency and amplitude could be measured using a built-in cursor with a digital readout. All recordings were repeated twice and then printed on thermal paper. Details of the technique as applied to human spinal surgery $y^{8}$ and experimental work in sheep ${ }^{9}$ have been described previously.

Once a baseline spinal SSEP waveform had been obtained $50 \mu \mathrm{g}$ isoproterenol were administered epidurally $\left(\mathrm{L}_{3-4}\right)$. Thirty minutes and $72 \mathrm{hr}$. later, spinal SSEP recordings were repeated.

The sheep were then rested in a hammock and were injected with $15 \mathrm{ml}$ lidocaine $2 \%$ epidurally. Spinal SSEPs were recorded before, 10 , and $60 \mathrm{~min}$ after the administration. The functional effects of each epidural block were grossly monitored by the presence of flaccid paralysis, mainly of the hind limbs, as a determinant of motor block. 
Group values are presented as mean \pm SEM and statistical analysis was performed using repeated measures analysis of variance followed by Dunnett $t$-test. A $P$ value $<0.05$ was considered significant.

\section{Results}

Twelve experiments were performed in six ewes. Mean weight was $65 \mathrm{~kg} \pm 8$.

Good baseline amplitude spinal SSEPs were obtained in each animal. Thirty minutes and $72 \mathrm{hr}$. after epidural injection of $50 \mu \mathrm{g}$ isoproterenol, the latency (resp. $P=0.3$ and 0.8 ) of the waves $(W)$ and the amplitude $(\mathrm{P}=0.9)$ were similar to baseline values (Table I).

After $15 \mathrm{ml}$ lidocaine $2 \%$ no spinal SSEPs could be generated in three sheep, whereas the latency from baseline of $\mathrm{W} 2$ in three other sheep was prolonged. $(P<0.02)$ and the amplitude was diminished $(P<0.001)$ (Table II).

\section{Discussion}

Several studies have been conducted to test the usefulness of isoproterenol as a marker of inadvertent intravascular injection in epidural anesthesia for labouring women. These studies mainly concerned the haemodynamic effects of $5 \mu \mathrm{g}$ isoproterenol when injected intravascularly in man and sheep. ${ }^{4,10}$ So far, the epidural use of isoproterenol is prohibited, because only one study exists concerning possible neurotoxic side effects. ${ }^{11}$ In this study, where isoproterenol was injected intrathecally in sheep, no histopathological changes of the spinal cord were found.

Evoked potentials have proved particularly valuable in showing subclinical spinal cord dysfunction. ${ }^{12}$ Toxic abnormalities of nervous system function can be divided into rapidly acting, usually reversible responses due to agents such as anaesthetics, and those of longer duration associated with physical disruption of cellular elements. ${ }^{12}$ No changes of spinal SSEP were recorded after the epidural administration of 10 times the dose of isoproterenol, which would be used as a test dose ( $5 \mu \mathrm{g}$ isoproterenol). In animal studies, general amplitude reduction of $\mathbf{5 0 \%}$ or complete loss of one component can be regarded as signifying a high likelihood of functional impairment of the spinal cord, ${ }^{13}$ although there is always the question of how sensitive SSEPs are to spinal cord damage. However, by injecting a neurotoxic compound ( $10 \mathrm{ml}$ pure alcohol epidurally) we demonstrated that marked changes in the SSEP (14 fold reduction of amplitude after one hour) could be generated. Due to the objections of our ethical committee, this experiment was performed in only one animal during isoflurane $1.5 \%$ anaesthesia.

In all the sheep lidocaine was injected in the epidural space to confirm the correct position of the

TABLE I Spinal somatosensory evoked potential $0,30 \mathrm{~min}$ and $72 \mathrm{hr}$ after $50 \mu \mathrm{g}$ isoproterenol epidurally. $; \mu \mathrm{V}=\mu$ Volt; $\Delta \mathrm{A}=\mathrm{Amplitude}$ of wave 1 (W1)-Amplitude of wave 2 (W2)

\begin{tabular}{|c|c|c|c|c|c|c|c|c|c|}
\hline \multirow[b]{2}{*}{ sheep 1} & \multicolumn{3}{|c|}{$\begin{array}{l}\text { Before isoproterenol } \\
W 1(\text { msec }) W 2(\text { msec }) \Delta A(\mu V)\end{array}$} & \multicolumn{3}{|c|}{$\begin{array}{l}30 \text { min after isoproterenol } \\
W 1 \text { (msec) } W 2 \text { (msec) } \triangle A(\mu V)\end{array}$} & \multicolumn{3}{|c|}{$\begin{array}{l}72 \text { br after isoproterenol } \\
W 1 \text { (msec) } W 2(\text { msec }) \Delta A(\mu V)\end{array}$} \\
\hline & 5.2 & 8.0 & 0.7 & 5.2 & 8.2 & 0.9 & 5.2 & 9.2 & 1.1 \\
\hline sheep 2 & 4.8 & 7.0 & 4.4 & 4.4 & 6.4 & 3.0 & 4.4 & 6.6 & 4.4 \\
\hline sheep 3 & 5.4 & 7.8 & 2.0 & 4.8 & 8.6 & 1.8 & 5.4 & 8.6 & 1.5 \\
\hline sheep 4 & 6.0 & 9.6 & 1.7 & 6.4 & 10.1 & 1.5 & 5.4 & 9.2 & 1.9 \\
\hline sheep 5 & 4.4 & 5.8 & 0.3 & 4.6 & 5.6 & 0.8 & 4.0 & 5.5 & 0.5 \\
\hline sheep 6 & 6.4 & 10.0 & 1.5 & 5.4 & 9.2 & 2.2 & 5.8 & 9.2 & 1.8 \\
\hline mean & 5.3 & 8.0 & 1.6 & 5.1 & 8.0 & 1.7 & 5.0 & 8.0 & 1.9 \\
\hline sem & 0.3 & 0.64 & 0.26 & 0.29 & 0.69 & 0.34 & 0.28 & 0.67 & 0.54 \\
\hline
\end{tabular}

TABLE II Spinal somatosensory evoked potential 0,10 , and $60 \mathrm{~min}$ after epidural administration of $15 \mathrm{ml}$ lidocaine $2 \%$; $\mathrm{a}=\mathrm{abolished}$ $\mu \mathrm{V}=\mu$ Volt; $\triangle \mathrm{A}=$ Amplitude of wave 1 (W1)-Amplitude of wave 2 (W2); $\quad P<0.05$

\begin{tabular}{|c|c|c|c|c|c|c|c|c|c|}
\hline \multirow[b]{2}{*}{ sheep I } & \multicolumn{3}{|c|}{$\begin{array}{l}\text { baseline } \\
W 1 \text { (msec) } W 2(\text { msec }) \Delta A(\mu V)\end{array}$} & \multicolumn{3}{|c|}{$\begin{array}{l}10 \text { min after lidocaine } \\
W 1 \text { (msec) } W 2 \text { (msec) } \Delta A(\mu V)\end{array}$} & \multicolumn{3}{|c|}{$\begin{array}{l}60 \text { min after lidocaine } \\
W 1 \text { (msec) } W 2(\text { msec }) \Delta A(\mu V)\end{array}$} \\
\hline & 5.2 & 9.2 & 1.1 & 5.4 & 8.0 & 0.07 & 5.0 & 10.4 & 0.2 \\
\hline shcep 2 & 4.4 & 6.4 & 4.4 & 5.4 & 11.0 & 0.2 & $\mathrm{a}$ & a & 0 \\
\hline shcep 3 & 5.4 & 8.6 & 1.2 & 5.6 & 9.2 & 0.7 & $\mathbf{a}$ & a & 0 \\
\hline sheep 4 & 5.5 & 8.8 & 1.7 & 5.7 & 10 & 0.2 & 7.2 & 12.4 & 0.04 \\
\hline sheep 5 & 4.0 & 5.5 & 0.5 & 7.8 & 9.2 & 0.6 & $\mathbf{a}$ & $\mathbf{a}$ & 0 \\
\hline sheep 6 & 5.6 & 9.4 & 1.9 & 6.6 & 8.2 & 0.9 & 7.1 & 12.8 & 0.05 \\
\hline mean & 5.4 & 9.1 & 1.8 & 5.9 & 8.7 & $0.45^{*}$ & 6.4 & $11.9^{*}$ & 0.09 * \\
\hline sem & 0.12 & 0.17 & 0.55 & 0.36 & 0.63 & 0.13 & 0.71 & 0.74 & 0.03 \\
\hline
\end{tabular}


epidural catheter and to evaluate the validity of this model. A decrease of amplitude and an increase in latency has been seen in other studies using local anaesthetics. Lidocaine $2 \%$ and bupivacaine $0.5 \%$ injected epidurally were unable to suppress SSEP completely to either dermatomal or peripheral nerve stimulation. ${ }^{15-18}$ The fact that in three sheep, after lidocaine, total abolition was seen is interesting. However, the other studies were conducted in humans, ${ }^{15-18}$ and lower doses were given. Also, SSEPs were recorded either at cortical ${ }^{15}$ or cervical vertebra levels. ${ }^{16-18}$ In a study where spinal SSEPs $\left(\mathrm{T}_{12}-\mathrm{L}_{1}\right)$ were measured after epidural $\left(\mathrm{L}_{3-4}\right)$ injection of $3 \mathrm{ml}$ bupivacaine $0.5 \%$ into monkeys, a progressively increasing latency and a decreasing amplitude were seen. ${ }^{19}$ Almost simultaneously with these events, a comparable attenuation of lesser duration was observed in the responses recorded from the upper thoracic cord evoked by conus medullaris stimulation, and responses recorded from the lateral conus medullaris evoked by sensorimotor cortex stimulation. ${ }^{19}$ Abolition of SSEPs in our study with the higher dosage of lidocaine is, in this regard, not so surprising. However, it was not the purpose of this study to evaluate the effects of lidocaine, but to evaluate the neurotoxic effects of isoproterenol.

In the present study, the spinal SSEPs recorded from the epidural space were considered more useful than cortical responses, on account of their electrical stability, which in an awake animal is of great importance. In addition, to record cortical responses, electrodes have to be placed precisely above the representive somatosensory area. Also, in experiments with local anaesthetics spinal SSEPs are more reliable, because they are less susceptible to fluctuations in blood pressure. Spinal responses can be recorded at much faster stimulation rates than cortical responses, with corresponding improvement in feedback time. ${ }^{13}$ There is evidence that distinct components of the spinal SSEP may be generated in different tracts of the spinal cord ${ }^{20}$, whereas the cortical response is likely to depend on the posterior columns alone. ${ }^{20,21}$

In conclusion, we found no change in amplitude or latency in SSEPs after epidural isoproterenol in a chronic awake sheep preparation. These results and an earlier studyll suggest that isoproterenol can safely be used epidurally, when given in low dose bolus injections.

\section{References}

1 Hood DD, Dewan DM, James FM III. Maternal and fetal effects of epinephrine in gravid ewes.

Anesthesiology 1986; 64: 610-3.
2 Cartwright PD, McCarroll SM, Antzaka C. Maternal heart rate changes with a plain epidural test dose. Anesthesiology 1986; 65: 226-8.

3 Leighton BL, Norris MC, Sosis $M$, Epstein R, Chayen B, Larijani GE. Limitations of epinephrine as a marker of intravascular injection in laboring women.

Anesthesiology 1987; 66: 688-91.

4 Leighton $B L$, DeSimone $C A$, Norris $M C$, Chayen $B$. Isoproterenol is an effective marker of intravenous injection in laboring women. Anesthesiology 1989; 71 : 206-9.

5 Starr A. Sensory evoked potentials in clinical disorders of the nervous system. Annual Review of Neuroscience 1978; 1: 103-27.

6 Krumbolz A, Weiss HD, Goldstein PJ, Harris KC. Evoked responses in vitamin $B_{12}$ deficiency. Ann Neurol 1981; 9: 407-9.

7 Shaw NA, Cant BR. The effect of pentobarbital on central somatosensory conduction time in the rat.

Electroencephalogr Clin Neurophysiol 1981; 51: 674-7.

8 Whittle IR, Johnston IH, Besser M. Spinal cord monitoring during surgery by direct recording of somatosensory evoked potentials. Technical note. J Neurosurg 1984; 60: 440-3.

9 Baines DB, Whittle IR, Chaseling RW, Overton JH, Johnston IH. Effect of halothane on spinal somatosensory evoked potentials in sheep. Br J Anaesth 1985; 57: 896-9.

10 Marcus MAE, Vertommen JD, Van Aken $H$, Wouters $P F$. Hemodynamic effects of intravenous isoproterenol versus epinephrine in the chronic maternal-fetal sheep preparation. Anesth Analg 1996; 82: 1023-6.

11 Marcus MAE, Vertommen JD, Van Aken $H$, Van Lommel F. Light microscopic neuropathological observations after intrathecal bolus injections of isoproterenol. Anesthesiology 1994; 81: A1175.

12 Arezzo JC, Simson R, Brennan NE. Evoked potentials in the assessment of neurotoxicity in humans. Neurobehavioral Toxicology and Teratology 1985; 7: 299-304.

13 Jones SJ, Edgar MA, Ransford AO, Thamas NP. A system for the electrophysiological monitoring of the spinal cord during operations for scoliosis. J Bone Joint Surg Br 1983; 65: 134-9.

14 Dolan EJ, Transfeldt EE, Tator CH, Simmons EH, $H u g h e s K F$. The effect of spinal distraction on regional spinal cord blood flow in cats. J Neurosurg 1980; 53 : 756-64.

15 Lund C, Selmar P, Hansen OB, Hjortso N-C, Keblet $H$. Effect of epidural bupivacaine on somatosensory evoked potentials after dermatomal stimulation. Anesth Analg 1987; 66: 34-8. 
16 Loughnan BA, Murdoch LJ, Hetreed MA, Howard LA, Hall GM. Effects of $2 \%$ lignocaine on somatosensory evoked potentials recorded in the extradural space. $\mathrm{Br} \mathrm{J}$ Anaesth 1990; 65: 643-7.

17 Loughnan BA, Fenelly ME, Hetreed MA, Hall GM. The effect of varying concentrations of bupivacaine on the somatosensory evoked potential to posterior tibial nerve stimulation. Acta Anaesthesiol Scand 1991; 35 (Suppl 96): 179.

18 Lougbnan BA, McHale SP, Welsh KR, Hall GM. Etidocaine and extradural somatosensory evoked potentials after posterior tibial nerve stimulation. $\mathrm{Br} \mathrm{J}$ Anaesth 1994; 72: 620-3.

19 Cusick JF, Myklebust JB, Abram SE. Differential neural effects of epidural anesthetics. Anesthesiology 1980; 53: 299-306.

20 Tsuyama N, Tsuzuki N, Kurokawa T, Imai T. Clinical application of spinal cord action potential measurement. International Orthopaedics 1978; 2: 39-46.

21 Halliday AM, Wakefield GS. Cerebral evoked potentials in patients with dissociated sensory loss. J Neurol Neurosurg Psychiat 1963; 26: 211-9. 